\title{
Responsibility Accounting on Amil Zakat Organization
}

\author{
Irda Agustin Kustiwi \\ Faculty of Economics and Business \\ Universitas Airlangga \\ Tjiptohadi Sawarjuwono \\ Faculty of Economics and Business \\ Universitas Airlangga
}

\begin{abstract}
Responsibility accounting carried out by organisations in the business sector is based more on material budgets. This budget is in the form of accumulated costs at the responsibility centre used to assess management performance. Islam explains that accountability based on alMishbah's interpretation has a broad essence. Responsibility accounting includes the relationship between humans (material), environmental (social), and creator (spiritual). This research uses a qualitative method with an exploratory case study approach. The case study approach was chosen because the context of responsibility accounting is an essential understanding of phenomena in the field. The exploratory type case study approach was chosen with the aim of the researcher to reconstruct the existing accounting responsibility in Nurul Hayat Surabaya following the terminology at the Al Mishbah interpretation. The results obtained that Nurul Hayat Surabaya has a vertical relationship to the creator, horizontal to direct stakeholders and indirect stakeholders, and a commitment that is in line with the four characteristics of Rasullullah. So according to the thought of the accounting accountability reconstruction researchers, what happened could be that in Nurul Hayat Surabaya, it could be following al-Mishbah's interpretation of Tijarah. Responsibility accounting is material, social and spiritual.
\end{abstract}

Keywords: Responsibility accounting; Amil Zakat; Social; Spiritual, Tafsir Al Mishbah

\section{Introduction}

Accountability has a relatively broad nature of understanding. Even in Islam's faith, it is recommended that each person own accountability to control himself from actions that exceed reasonableness limits. The Prophet's hadith support it in Mustaq (2001), which is that "every human being is a leader, and the leader is responsible for his people as best as possible." Hadith explains that accountability is natural and exists in humans as leaders. Therefore, it is needed to carry out obligations as caliph to be accounted for in the future.

Then, how is the relationship between business responsibility from the perspective of Islamic accounting?. Indeed, many studies are needed to be carried out in its practical application. Accounting based Islamic values, better known as Islamic accounting, require a more elaborate explanation because it recognises individual freedom in carrying out business activities. Unlike conventional accounting, the application of business accountability is more likely to be influenced by the understanding of capitalism. Capitalism is used as a basic ideological guideline of accounting to prioritise capital owners' interests (Belkaoui in Harahap, 2001).

Capitalist accounting describes matter as the primary goal of organisations in 
business thinking. The goal is to maximise profits by paying attention to operational issues and financial budgets by establishing an accountability centre known as accountability accounting. Fowzia (2011) defines responsibility accounting as part of a sound system for accumulating and reporting costs adjusted to the responsibilities of each individual controlled by them. Accountability accounting is a management accounting line that describes the relationship between the organisation's responsibility centre and the standard measure of who does, the costs involved, and the achievements obtained.

Fowzia (2011), Mojgan and Safa (2012), Siyanbola and Raji (2013) conducted research that explains the significant relationship between accountability accounting which is based on budgeting as a tool for measuring management performance. The assessment is carried out using a cost control reference measured through the organisational management structure, budget preparation, cost separation systems, account coding systems, and accountability reporting systems. In contrast to Aliu (2013) and Prang (2013), accountability accounting has not been practical based on cost control. The organisations that carry out are included on a small scale so that there is no separation of costs by management.

Lee, quoted by Usmansyah (1989), states a shift in the essence of responsibility in accounting in terms of practice and theory, which is called social responsibility accounting. The accountability paradigm, which was initially recognised as a tool for capital owners' welfare, has developed into a tool to benefit the environment. The social value held in accounting describes more than just seeking a profit. Kristiana, Yaningwati, and Nuzula (2014), Luhgiatno. (2007), and Tuan (2017) state that organisations carry out social activities to contribute to society and the environment by compiling costs into accountability accounting reports. In contrast to Wijaya (2012), which shows that the cost of leverage, probability, level of commissioners, and size of the organisation has a significant negative effect on social responsibility accounting.

This paradigm is the source of the researchers' ideas to carry out a more indepth exploration of the responsibility accounting applied in business. Following the Islamic perspective, business people can make things easy for others rather than just being oriented towards profit. Researchers want to describe and describe more complex responsibility accounting. Accounting is a tool that can be used for accountability to God, not only for humans' benefit. This thought is essential to study more deeply because accounting is an instrument that can be used to draw closer to Allah (Triyuwono, 2006).

Responsibility accounting describes harmony in material, social and spiritual aspect. Material is used as a form of management responsibility to provide information to owners of capital. Social is defined in order to communicate the accountability of the organisation to the surrounding community. Spiritual is expected to be a role model in the final management performance process's essential attitude and ethics that illustrates the creator's understanding. The understanding of accountability is following the work of Shihab (2011) in the Al Mishbah interpretation book, the terminology at Tijarah (business), which consists of material, immaterial, and material immaterial properties. The discussion regarding the at Tijarah tafsir Al Mishbah is also quoted and explained economically by Darussalam, Malik, and Hudaifah (2017). In essence, the business model of the word at Tijarah tells of inviting business to prioritise Islamic values. The mechanism for accountability accounting is prioritised for Allah in addition to management.

Regarding the selection of the book $\mathrm{Al}$ Mishbah, especially the terminology at Tijarah by Shihab (2011), because the most recent book published by Indonesians uses Indonesian. It is evident from the printed book of the Al Mishbah commentary, which was published in 
2011. Another reason is the interpreter's background, who is a traveller, has various social and cultural knowledge in interpreting the holy verses of the Quran in a contemporary way. Agree with Anshori (2018), Darussalam, Malik, and Hudaifah (2017), and Mawangir (2018) even though they do not describe it thoroughly, but the community can accept the interpreter's understanding and under the research idea.

Nurul Hayat is part of the amil zakat organisation with its uniqueness and is appropriate to be used as an object in research. First, Nurul Hayat was recognised and appreciated by BAZNAS as an organisation engaged in the best national zakat sector in 2018, increasing the best ZIS funds in 2017 (www.nurulhayat.org/, accessed on 5 June 2019). Second, the amil zakat organisation chooses a decentralised system in its business centre, so that branch management does not need to depend on the centre or donors and become an independent organisation. Mandiri means promoting transparency and accountability in managing the mandate given by donors and muzaki to be maximally distributed. Third, Nurul Hayat sticks to his vision, namely to serve Allah by building up the people. It is evidenced in every operational activity that is guided by the faith and sharia according to Islamic values.

The main problem in this research is constructing accountability accounting that has been done by business people in making accounting reports according to Islamic values, especially following the terminology at Tijarah tafsir Al Mishbah. Responsibility accounting consists of material, social, and spiritual characteristics. Accounting is used to explain the economy in monetary terms and translate how it is in line with Islamic society's views.

\section{Literature Review and Hypothesis Development}

\section{Material Accounting Responsibility}

It is undeniable that every organisation must have an ultimate goal that prioritises profit. To maximise profit achievement, it is necessary to have efficient planning and control, namely, accountability accounting. Accountability accounting is an instrument that is useful for controlling costs reported following a particular unit of responsibility. The information reported in responsibility accounting is crucial because it explains the leaders' influence on design and realisation. The control that is carried out can be a role setting for leaders based on a budget that contains a plan of costs and revenues.

Responsibility accounting also describes the organisational management structure in detail. The management structure makes it easier for leaders in the division of responsibilities and tasks assigned so that oversight of irregularities can be carried out by tracking who is responsible (Siyanbola and Raji, 2013). Besides, the cost budgeting process carried out by each department can be used to control costs according to the planned budget. The organisation's ultimate goal will be achieved if cost control is carried out efficiently through cost separation and account codes classification. In other words, organisations that carry out accountability accounting based on a budget with the final form of a material accountability report.

H1. There is material responsibility accounting.

\section{Immaterial Responsibility Accounting}

Social responsibility accounting is a part of accounting that uses organisational policies in terms of social benefits and social costs (Harahap, 2001). Business entities, organisations, are expected to be willing and able to contribute to society and the environment. The organisation's obligations are not only to shareholders economically but to other parties with socialist interests.

The way of assessing social responsibility accounting is based on the number of social activities carried out and the costs incurred. Besides, organisations can disclose additional social 
responsibility reports in the form of valueadded statements. This report is significant for organisations that consider employees and the environment as part of their stakeholders. Triyuwono (2012) supported the above statement, which explains that the accountability pattern carried out by organisations horizontally is linked to fellow humans and the existing universe.

H2. There is social responsibility accounting.

\section{Spiritual Responsibility Accounting}

Accounting science's syahada is the ultimate goal of understanding accounting that believes in God in it (Alimuddin in Anshori, 2018). Accounting can be said to be appropriate if it is used as an instrument to get closer to the creator. By paying attention to the spiritual element, Nurul Hayat Surabaya is expected to emulate the Prophet's four main characteristics in applying accountability accounting.

The four pillars of the Prophet's character consist of Shiddiq, Amanah, Fathanah, and Tabligh. These characteristics have a universal meaning, which means that they should be applied in human lifelines, including business. According to the sharia perspective, the Prophet's character behind business success is the critical success factor in shaping business people's character (Mawangir 2018), and Shihab (2011). However, the reality is rarely implemented in the business sector.

\section{Shiddiq}

Organisations need Shiddiq in the application of accountability accounting to suit Islamic values in budget management. Shiddiq is carried out by management as concrete evidence in promoting transparency and accountability in managing budgeting activities. The words and actions carried out to align with the budget, which contains the organisation's goals. Hasan (2009) states that the budget prepared is useful for optimising its strategic business goals.

\section{Amanah}

Accountability accounting exemplifies mandate as the next value after Shiddiq. Amanah, which means trustworthiness, is a crucial element to be carried out by management in maintaining the responsibilities that have been given comprehensively and implemented as well as possible following the management structure The absence of mandate value in management can result in enormous losses for the organisation. Damayanti (2004) states that an organisation is categorised as healthy if it has clearly divided functional tasks and defined authority and responsibility in a mandate manner.

\section{Fathanah}

Another Islamic value needed in an organisation is the nature of Fathanah. Fathanah generalised as intelligent, reflecting the nature of the Prophet Muhammad identified by researchers as an expert and professional in accountability accounting. The nature of Fathanah is needed in doing business to manage the organisation by setting strategic goals by implementing a system of separating controlled and uncontrolled costs in the application of responsibility accounting. Mawangir (2018) explains that management requires good management to be implemented following management objectives to form human resources with good character and reason.

\section{Tabligh}

Tabligh is the Prophet's last characteristic and the final process of the responsibility accounting requirements in an accountability report. The accountability report is a draft that explains the results of the application of the responsibility accounting concept, which plays an essential role in planning and monitoring activities for the organisation's operations. The accountability report summarises the results achieved by a leader who applies the value of Tabligh in carrying out duties and authorities during a specific period. Harahap (2001) explains that the pressure 
of accounting is not on decision making but Tabligh (accountability).

H3. There is spiritual responsibility accounting.

\section{Methods}

The selection of the appropriate research method for this research is an exploratory case study. This selection was carried out following Yin (2014). This study will discuss responsibility accounting construction based on the Tijarah Tafsir Al Mishbah following the Al-Quran verse in the Nurul Hayat Surabaya Amil Zakat organisation. This construction consists of three categories of accountability accounting relationships between humans to fellow humans (material in nature), between humans to fellow humans and Allah to humans (social), and between humans to God (spiritual).

Researchers will also collect the required data obtained from observation sources, interviews from sources, and documentation. The information obtained will be processed by checking the authenticity of the data. Triangulation is done by collecting data related to accountability accounting at Nurul Hayat Surabaya. Next, check the consistency between data/information obtained from observation sources with interviews and document sources. Finally, conclude checking the data. If there is consistency between the data collected through observation, interview, and document sources, it can be said that the data collection method is reliable.

The data analysis technique is obtained through collecting, compiling, and interpreting data from the observations. The existing data will then be compared one by one and adjusted to the theory related to responsibility accounting. Comparisons aim to obtain valid results and answer research questions. The meaning of the data is also carried out to interpret the information obtained. Researchers chose to use Yin (2014) pattern matching technique by making comparisons.

\section{Results and Discussion}

\section{Material Accountability Accounting}

Nurul Hayat Surabaya has implemented accountability accounting conventionally. This convention tends to be material in nature based on, among other things, management structure, budget preparation, cost separation systems, account coding systems, and accountability reports that have been carried out. The organisational management structure explains the construction of tasks and responsibilities that have been clearly and divided for the management level (Mojgan and Safa, 2012). This division is important because it relates to the assignment of responsibilities between the responsibility centres in achieving the goal of being an organisation belonging to the people. Independently. The management composition at Nurul Hayat Surabaya has clearly described the levels of authority, responsibility, and duties of each division level. The central fund section and the ZIS management program centre have also clearly formulated each work unit's duties and responsibilities regarding who is responsible for each section.

Budgeting in Nurul Hayat consists of costs incurred in each part of the unit manager. How to measure it by comparing the realisation and the budget. Fees will be collected and then separated based on the account code according to its management level. Each management level will be burdened with the responsibility associated with a cost centre that can be separated from cost control methods. The organisation's existing budget uses a practical method, which means that the preparation process is adjusted to the organisation's past circumstances (Harahap, 2001). The budgeting process has been carried out by planning according to the annual budget work meeting. The budget set is based on the results of last year's budget meeting compared to the realisation that has been used this year. Later the results used are adjusted to projected future needs. 
Cost management is carried out by separating controlled and uncontrolled costs at the accountability centre since the budget stipulates (Adnyani, 2015). The purpose of cost separation is to know the limits of their respective responsibilities and not experience multiple responsibilities. Based on interviews that have been conducted with internal parties, the organisation has indeed divided the responsibility centre but has not yet separated controlled and uncontrolled costs because only controlled costs can be accounted for.

Coding of account accounts is an essential part of the accounting system by classifying data grouped according to the character of organisational costs (Damayanti, Adnyani, 2015). Nurul Hayat
Surabaya's account code classification has been linked to the accountability centre within the organisation. Thus, the existing account code has shown the responsibility centre's authority and can provide information about where costs occur and who will be responsible for the incurred costs.

The accountability report contains information to management regarding the implementation of each unit's work results in Nurul Hayat. This information is useful for management control in maintaining activities that occur in the organisation. Besides, information serves as decision making for interested parties. The following is the accountability report system that has been carried out by the program division, namely:

Table 1. Budget and Realisation

\begin{tabular}{rlrcc}
\hline No & Sector & \multicolumn{1}{l}{ Budget } & Realisation & Budgeting Realisation \\
\hline 1 & Da'wah & $14,604,330,134$ & $14,478,575,615$ & $99 \%$ \\
2 & Economy & $2,678,400,000$ & $658,626,050$ & $25 \%$ \\
3 & Health & $4,551,650,000$ & $2,762,740,163$ & $61 \%$ \\
4 & Social Humanity & $18,664,648,366$ & $23,669,302,814$ & $127 \%$ \\
5 & Education & $25,335,519,891$ & $26,925,896,569$ & $106 \%$ \\
\multicolumn{2}{l}{ Total } & $65,834,548,391$ & $68,495,141,211$ & \\
\hline \multicolumn{2}{l}{ Average budget realization (\%) } & \multicolumn{2}{c}{$84 \%$} \\
\hline
\end{tabular}

Nurul Hayat Surabaya designed traditional-based responsibility accounting to be material in facing a dynamic business environment. Accountability accounting is material in nature less suitable to be applied as an amil zakat organisation. Therefore, Nurul Hayat Surabaya must innovate to compete with other places and maintain donors' trust by providing responsible accounting from a social and spiritual perspective.

\section{Social Accountability Accounting}

Nurul Hayat has a program centre whose activities consist of distributing and utilising community funds to carry out social responsibility to the community. The standards governing ZIS funds' disbursement follow BAZNAS Regulation
No.3 of 2018 (Anshori, 2018). The implementation of zakat management is reflected in the nominal amount distributed and utilised, depending on fundraising or fundraising. Therefore, Amil must have the ability to carry out the collection to ensure the exact and maximum results obtained.

The collection carried out by the zakat officer or Amil zakat Nurul Hayat Surabaya in 2018, the total revenue that was able to be collected by Amil Nurul Hayat was Rp. $76,801,945,316$, with a total donation of Rp. $66,613,370,263$. The output of zakat management at Nurul Hayat is distribution and utilisation. At Nurul Hayat Surabaya this division is better known as LaySos (Layanan Sosial). 
Layanan Sosial is part of Amil from the organisation that is responsible for the utilisation of zakat funds that have been collected by the collection team. The social service division in implementing its utilisation is divided into two departments: charity or dhoruroh and long-term empowerment.

Charity is a distribution carried out in a consumptive nature, which means that zakat funds are distributed or distributed to meet the moment's needs. In contrast to long-term utilisation, it is a form of distribution that aims to empower Mustahik, which is the goal and target of long-term distribution is to change the Mustahik mindset through entrepreneurship programs. The long-term utilisation program is intended to make Mustahik more independent and able to become Muzakki. The implementation of long-term utilisation has goals that must be achieved, and there is supervision carried out to measure the implementation of the utilisation until it reaches predetermined goals. The fastest implementation of long-term empowerment can be felt for four months of supervision, and the longest provided for assistance is four years. The achievement of the empowerment mechanism carried out by Nurul Hayat has been following a firmly held commitment. Achievements and appreciation were also obtained from several parties such as the pro-poor award from the provincial government of East Java.

\section{Spiritual Accountability Accounting}

Accounting can be an instrument of responsibility carried out by Nurul Hayat Surabaya by paying attention to the spiritual dimension. The spiritual dimension explains that accountability reporting is made to Allah as the creator by imitating the Prophet's four characteristics applied in accountability accounting. Shiddiq, Shiddiq has a role in budgeting activities in the accountability accounting of Nurul Hayat Surabaya. Before preparing a budget, of course, management must first understand the purpose and function. In this case, one of the objectives of budgeting is the organisational commitment to stand independently. Mandiri is Nurul Hayat Surabaya's first commitment without taking ZIS funds for operational needs, especially for existing employee salaries.

Researchers reconstruct Shiddiq as honest and trustworthy in responsibility accounting in the budget preparation section. Management requires a Shiddiq character so that the recording is carried out correctly following the reality that occurs in the field. Measurements made by organisations through the use of funds according to budget and compliance with regulations to avoid office and corruption misuse.

Amanah, Nurul Hayat Surabaya's second commitment is an organisation that has Amanah. Why? Because what is mandated is Islam's part, its management is also according to sharia values. This identification is vital for setting zakat accounting objectives in line with organisational goals. Nurul Hayat publishes financial reports periodically to account for the organisation's performance during the period concerned. An independent examiner will check the report to test the report's validity and build and increase public trust - a different understanding of Amanah by researchers based on responsibility accounting. Amanah, is analogous to carrying out tasks following the delegation of given authority. Period of management composition that occurs every five years with a maximum term of two times.

Fathanah, Based on the results of interviews with resource persons, professionalism is part of the organisational commitment that comes from the value of Fathanah. This value is useful for establishing a quality management system in managing zakat and describes an organisational culture consisting of concise, neat, tidy, care and diligent as its motto. Accountability accounting related to the Fathanah value is seen in management's ability to manage the cost separation system and classify the account coding system. The cost 
separation system is required to contain information that meets materiality criteria. Information is considered material if the failure to include or errors in the separation of controllable and uncontrollable costs can affect users' economic decisions based on the accountability report. Nurul Hayat Surabaya carried out the account coding system by recording transactions linked to the accountability centre. So, the usual account code is the group number code. This code defines where the data occurs and reflects the Fathanah value in the professionalism of cost information.

Tabligh, Tabligh has an essential role in the responsibility accounting process at Nurul Hayat Surabaya. The role of Tabligh is the delivery of accountability information carried out by the organisation. Organisational success is not only measured through the achievement of final goals but the process of empowering accountability activities following Nurul Hayat's commitments. Empowerment is a form of management accountability for managing community funds which will later be continued into accountability reports.

\section{Conclusion}

The conclusions obtained from applying accountability accounting in the amil zakat organisation Nurul Hayat Surabaya based on the terminology at Tijarah tafsir $\mathrm{Al}$ Mishbah are separated into three characteristics. First, the form of accountability accounting in Nurul Hayat Surabaya, which is material as a whole, has been fulfilled except for the controlled and uncontrolled cost separation system elements. Second, the advanced form of social responsibility accounting is carried out by Nurul Hayat Surabaya using a good performance approach. It is proven that the organisation has carried out several social activities as a form of its responsibility, namely distribution and utilisation. Finally, the spiritual form of accountability accounting at Nurul Hayat Surabaya has exemplified the Prophet's nature. The nature of the apostle is attuned to organisational commitment, namely
Shiddiq (independent), Amanah, Fathanah (professional), and Tabligh (empowering). Nurul Hayat firmly holds this commitment to accountability accounting.

\section{References}

Adnyani, N. P. 2015. Penerapan Akuntansi Pertanggungjawaban Sebagai Alat Pengendalian dan Penilaian Kinerja Manajer Produksi (Studi Kasus Pada Pabrik Putri Nanda). Jurnal Akuntansi Universitas Negeri Surabaya.

Aliu, S. 2013. Penerapan Akuntansi Pertanggungjawaban Sebagai Pengendalian Biaya Produksi Dan Penilaian Kinerja. Jurnal EMBA, Vol. 1 No. $3: 160-168$.

Anshori. 2018. Studi Ayat-ayat Zakat Sebagai Instrumen Ekonomi Islam dalam Tafsir al-Misbah. Jurnal Kajian Islam dan Masyarakat, Volume 29, No. 2.

Damayanti, E. 2004. Penerapan Akuntansi Pertanggungjawaban Melalui Pusat Biaya Sebagai Alat Pengendalian Manajemen Pada PT. Pos Indonesia (Persero). Jurnal Ekonomi dan Bisnis, Volume 2.

Darussalam, A. Z., Malik, A. D., dan Hudaifah, A. 2017. Konsep Perdagangan Tafsir Al-Mishbah (Paradigma Filsafat Ekonomi Qur'ani Ulama Indonesia). Jurnal Al Tijarah, Vol. 3, No.1, Juni 2017 (45-64).

Fowzia, R. 2011. Use of Responsibility Accounting and Measure The Satisfaction Levels of Service Organisations in Bangladesh. International Review Of Business Research Papers, Vol. 7. No.5: 53-67.

Harahap, S. S. 2001. Analisis Kritis Atas Laporan Keuangan. Cetakan Kedua. Jakarta: PT. Raja Grafindo Persada.

Kritiana, E., Yaningwati, F., dan Nuzula, N. F. 2014. Penerapan Akuntansi Pertanggungjawaban Sosial Sebagai Bentuk Tanggung Jawab Perusahaan Terhadap Lingkungan Sekitarnya (Studi Pada PT. Petrokimia Gresik). Jurnal 
Administrasi Bisnis, Vol. 17 No 1 Desember 2014.

Luhgiatno. 2007. Akuntansi Sosial Bentuk Kepedulian Perusahaan Terhadap Lingkungan (Social Accounting is A Attention Corporate Model by Environment). Jurnal Fokus Ekonomi, Volume 2, Halaman: 1-16.

Mawangir, M. 2018. Nilai-nilai Pendidikan Karakter Perspektif Tafsir alMishbah Karya Muhammad Quraish Shihab. Tadrib: Jurnal Pendidikan Agama Islam, Vol. 4, No. 1.

Mojgan, dan Safa. 2012. Examining The Role of Responsibility Accounting in Organization Sructure. American Academic \& Scholarly Reseacrh Journal Special Issue (4), No. 5.

Mustaq, A. 2001. Etika Bisnis dalam Islam. Jakarta: Pustaka Al Kautsar.

Prang, S. O. 2013. Penerapan Akuntansi Pertanggungjawaban Dengan Anggaran Sebagai Alat Pengendalian Untuk Penilaian Kinerja Pada PT. Pelayaran Nasional Indonesia Cabang Bitung. Jurnal EMBA. Vol. 1 No. 4 Hal. 1175-1184.

Shihab, M. Q. 2011. Bisnis Sukses Dunia Akhirat. Jakarta: Lentera Hati.

2011. Tafsit Al Mishbah.

Jakarta: Lentera Hati.

Sumarno, M. S. 2014. Perlakuan Akuntansi Zakat Pada Badan Amil Zakat (Studi Kasus Pada Badan Amil Zakat
Kabupaten Sidoarjo). Jurnal Akuntansi Universitas Surabaya.

Siyanbola, T. T. and Raji, G. M. 2013. The Impact of Cost Control on Manufacturing Industries Profitability. International Journal of Management and Social Science Research, Vol 2 , No. 4 : 1-7.

Triyuwono, I. 2006. Akuntansi Syariah: Menuju Puncak Kesadaran Ketuhanan Manunggaling Kawulo-Gusti. Pidato Pengukuhan Guru Besar Akuntansi Syariah, 2 September 2006. Malang.

2012. Akuntansi Syariah: Perspektif, Metodologi, dan Teori. Jakarta: Rajawali Pers.

Tuan, T. T. 2017. Application Responsibility Accounting to Sustainable Development in Vietnam Manufacturers: An Empirical Study. Economics World Journal, Volume 5, No. 6, Pages: 573-583.

Usmansyah. 1989. Telaah Alternatif Penerapan Akuntansi Pertanggungjawaban Sosial di Indonesia. Jurnal Akuntansi, No. 10, Oktober, Halaman 31-34.

Wijaya, M. 2012. Faktor-faktor yang mempengaruhi Pengungkapan Tanggung Jawab Sosial pada Perusahaan Manufaktur yang terdaftar di Bursa Efek Indonesia. JIMA, Vol 1 No 1 Januari 2012.

Yin, R. K. 2014. Studi Kasus Desain \& Metode. Jakarta: Rajawali Pers. 